\title{
Resetting international systems for pandemic preparedness and response
}

\author{
Sudhvir Singh and colleagues summarise the recommendations of the Independent Panel for \\ Pandemic Preparedness and Response to try to prevent future pandemics
}

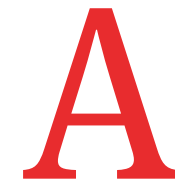

t the World Health Assembly in May 2020 there was consensus from all governments on the need for a comprehensive, impartial, and independent review of the international health response to covid-19. ${ }^{1}$ Tedros Adhanom Ghebreyesus, the World Health Organization's director general, took the decision to establish an Independent Panel for Pandemic Preparedness and Response. He appointed Ellen Johnson Sirleaf and Helen Clark as co-chairs and gave them authority to choose panel members and work independently. The panel systematically examined evidence through a structured programme of work that included literature reviews, interviews, 15 expert round tables, and six hearings with affected groups. WHO also gave the panel access to its documentation. The panel published its recommendations on 12 May $2021 .^{2}$ This article discusses

\section{KEY MESSAGES}

- The Independent Panel for Pandemic Preparedness and Response has recommended action after failings in the international response to the covid19 pandemic

- The panel considers pandemic preparedness and response to be a global public good

- Pandemic threat should be elevated to the highest leadership level and pandemic preparedness and response treated as the responsibility of the whole of government and society

- Stronger leadership and better coordination are needed at national, regional, and international levels, including a more focused and independent WHO, a pandemic treaty, and a new global health threats council

- Agreement on a package of reforms is needed to ensure that the world can prevent the next outbreak of a new pathogen becoming another pandemic its diagnosis and summarises the recommendations how the international system can be better prepared for the future. Other articles in the series consider the findings in more detail (www.bmj.com/covid-19-preparedness-and-response).

\section{The diagnosis}

The panel found critical failings at each step of the covid-19 response from preparedness to detection and alert and in both the early and the sustained response. ${ }^{2}$ Indices of how prepared countries were for pandemics proved inaccurate, having given insufficient weight to the effect of inequities, political leadership, and trust. ${ }^{3}$ The international alert systems, including the International Health Regulations (IHR) mechanisms, were not swift enough. ${ }^{4}$

Time was lost as SARS-CoV-2 spread. WHO's director general declared the highest alert possible, a public health emergency of international concern (PHEIC) on 30 January 2020 on the recommendation of the second meeting of the IHR emergency committee convened to consider the outbreak. This was a full month after spread had first been drawn to WHO's attention. ${ }^{5}$ Subsequently, only a few countries put in place comprehensive and coordinated measures to contain and stop the spread of the virus. The global and national response failed to prevent a wide and deep social and economic crisis, and inequities have been amplified, as evidenced by maldistribution of vaccines and other essential tools. ${ }^{6}$

Although multiple previous reports had warned of the dire threat posed by pandemics before covid-19 emerged, the panel concluded that the potential to cause systemic collapse was not appreciated globally. ${ }^{78}$ Pandemics and other severe health threats were largely not on the agendas of heads of state or government in the same way as they continuously appraise threats of war, terrorism, nuclear disaster, and global economic instability. Instead, pandemic preparedness and response were largely siloed within the health sector, and despite occasional high level health security discussions and scenario exercises, there was little integration of pandemic threat into whole of government planning, except in countries with recent experience of the health, social, and economic effects of epidemics.

A complex and fragmented international health system resulted in delays and incoherence in response strategies. The IHR proved to be a conservative rather than a proactive instrument of international law. Declaration of a public health emergency was not as fast as it should have been, and the response was sluggish as countries had no specific obligations to act. Financial resources to respond rapidly to the emerging pandemic were not available. The World Bank's Pandemic Emergency Financing Facility, established to provide surge funding in 2017, had exhausted funds available through its cash window on Ebola response and its insurance based financing proved overly cumbersome and was not triggered until three months after the international public health emergency was declared, by which time the pandemic was well established. ${ }^{9}$

Platforms to support the rapid development of therapeutics, diagnostics, and vaccines did not exist and had to be established during the crisis. The most successful element, vaccine development, built on existing structures, including the Coalition for Epidemic Preparedness Innovations (CEPI), but allocation strategies had not been determined in advance and product development pathways were not aligned to global needs. Mechanisms were not available to coordinate between national, regional, and global levels and overcome national competition when needs for supplies and essential response workforces surged.

The panel's comparative analysis of national responses to covid-19 has shown that the most effective responses were those which established effective multisectoral coordination reporting to the highest level of government. ${ }^{10}$ Leadership was lacking, with many national responses dominated by short term domestic political dynamics that militated against cooperative and solidaristic solutions 
and ability to adapt to rapidly changing circumstances. At both national and international levels public health and economic mitigation efforts were not synchronised and mutually supportive; nor was there a common vision for trade and intellectual property regulation. The market driven scramble for tools and supplies, including vaccines, has resulted in grossly inequitable access.

\section{Package of recommendations}

The panel's recommendations seek to overcome the twin challenges of ensuring that tackling pandemic threat is raised to the highest leadership level and that pandemic preparedness and response are treated as responsibilities of the whole of government and society. Given the piecemeal implementation of recommendations from previous post-pandemic reviews, the panel proposed a package of measures to be implemented as a whole, including strengthening WHO, a new pandemic treaty, a financing mechanism, and a global health threats council for heads of state and government to ensure ongoing political commitment. ${ }^{6}$

The panel called for a political declaration, to be adopted by heads of state and government at a special session of the UN General Assembly convened for this purpose. Such a process could commit all countries to transform the international system for pandemic preparedness and response and establish a future roadmap, tying together the respective initiatives of the World Health Assembly, the G20, and others. Figure 1 visualises the package of recommendations proposed by the panel and further details are available in table 1.

\section{Global health threats council}

Establishment of a global health threats council is proposed to secure high level political leadership for, and ongoing attention to, pandemic prevention, preparedness, and response, and to enhance accountability at all levels. A similar recommendations was made after the west Africa Ebola outbreak, ${ }^{8}$ but was not implemented because of perceptions that it would weaken WHO. ${ }^{11}$ Instead, the Global Preparedness Monitoring Board was launched in May 2018, coconvened by WHO and the World Bank.

The global health threats council's functions would be to

- Maintain political commitment to pandemic preparedness between emergencies and to response during emergencies

- $\quad$ Monitor progress towards pandemic goals and targets set by WHO

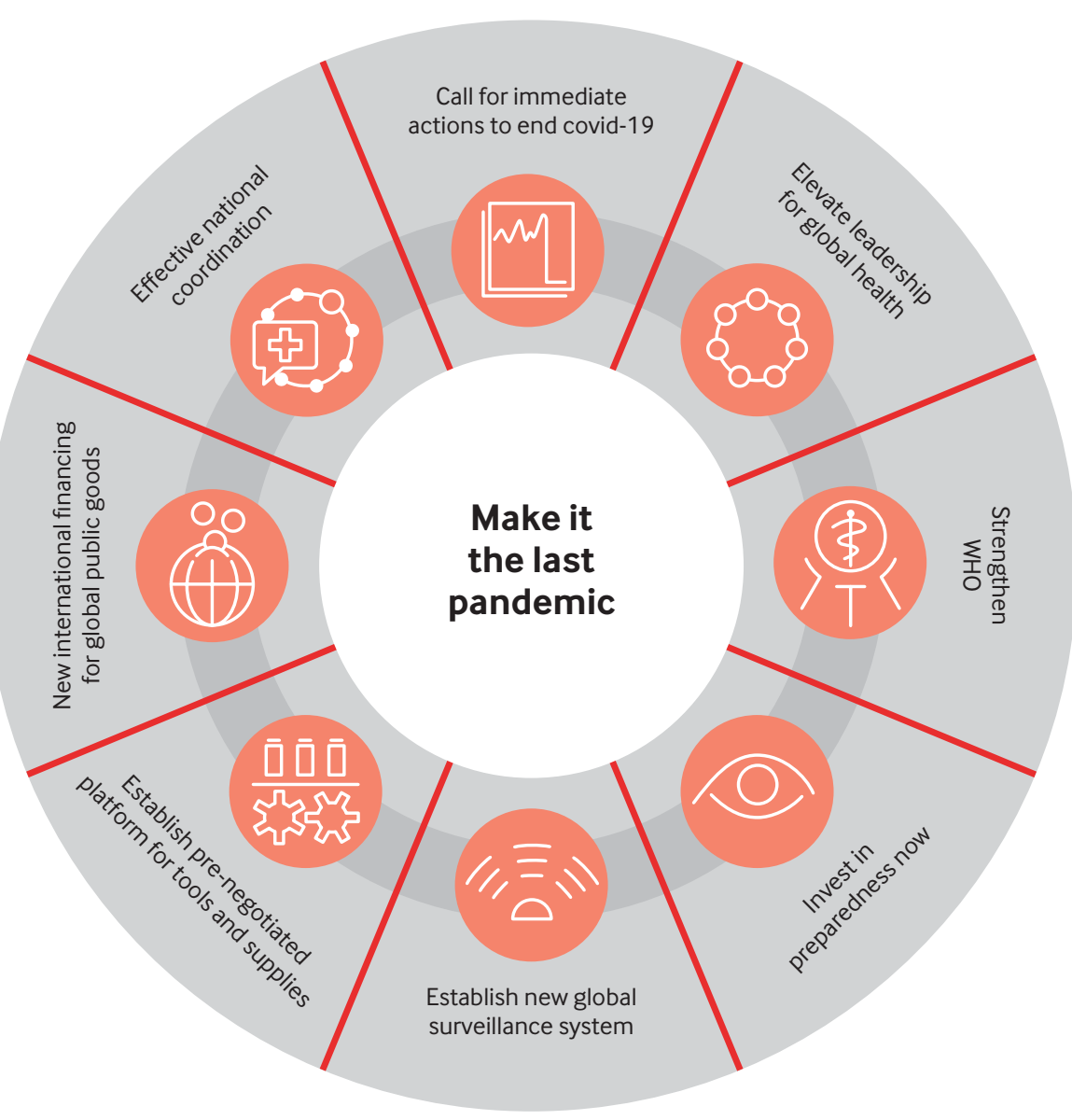

The council's membership would comprise heads of state and government and include private sector and civil society representation. ${ }^{1}$ It would interact with key stakeholders, including the UN secretary general, WHO director general, executive director of the International Monetary Fund (IMF), and the president of the World Bank Group. The panel also recommended enhanced accountability mechanisms which would inform the council, including universal periodic peer review of pandemic preparedness and response capacities facilitated by WHO, and regular pandemic preparedness assessment and evaluation of economic policy response plans by the IMF as part of its mandated formal consultations with countries. The council would serve to galvanise global efforts; it would not have directive authority in relation to specific international organisations and it would not take on operational functions.
To ensure the council would have wide legitimacy, the panel recommended that it be instigated by the UN General Assembly. The panel also recommended that the G20 nominate one of the council's three co-chairs. The proposed council features in the communique from the G7 leaders' summit in June 2021, ${ }^{12}$ and establishing the council was put forward as a target at the covid-19 summit convened by US President Biden during the 2021 UN General Assembly leaders' week.

The global health threats council is intended to deal with several shortcomings the panel found in the international Covid19 response, including the effective paralysis of the UN Security Council, where the role of WHO became a token of geopolitical division. Its inclusive composition would seek to overcome the logjam of geopolitical competition and sectoral interests that have hampered the pandemic response to date.

\section{Financing}

The panel has proposed a new international pandemic financing facility to raise additional reliable financing for preparedness and for surge funding in case of a 


\begin{tabular}{|c|c|c|}
\hline Actions & Main organisation & When \\
\hline \multicolumn{3}{|c|}{ Elevate political leadership for global health to the highest levels to ensure leadership, financing, and accountability } \\
\hline Establish a global health threats council & United Nations General Assembly & $\begin{array}{l}\text { Late } 2021 \\
\text { (UNGA Special } \\
\text { Session) }\end{array}$ \\
\hline Adopt a pandemic framework convention using the powers under article 19 of the WHO constitution & WHA decision & $\begin{array}{l}\text { November WHA } \\
\text { Special Session }\end{array}$ \\
\hline $\begin{array}{l}\text { Adopt a political declaration by heads of state and government at a global summit under the auspices of the UN } \\
\text { General Assembly at a special session convened for the purpose }\end{array}$ & United Nations General Assembly & Late 2021 \\
\hline \multicolumn{3}{|l|}{ Focus and strengthen the authority and financing of WHO } \\
\hline $\begin{array}{l}\text { Establish WHO's financial independence; strengthen the authority and independence of the director general; } \\
\text { strengthen the governance capacity of the executive board, including by establishing a standing committee } \\
\text { for emergencies; focus WHO's mandate on normative, policy, and technical guidance; empower WHO to take a } \\
\text { leading, convening, and coordinating role in operational aspects of emergency response }\end{array}$ & WHA decision & May 2022 \\
\hline Resource and equip WHO country offices sufficiently to respond to technical requests & WHO Secretariat & Immediately \\
\hline Prioritise the quality and performance of staff at each WHO level & WHO Secretariat & Short term \\
\hline \multicolumn{3}{|l|}{ Invest in preparedness now to create fully functional capacities at the national, regional, and global level } \\
\hline WHO to set new and measurable targets and benchmarks for pandemic preparedness and response capacities & WHO/national governments & Q 3-4 2021 \\
\hline $\begin{array}{l}\text { All national governments to update their national preparedness plans against the targets and benchmarks set } \\
\text { by WHO }\end{array}$ & National governments & Within 6 months \\
\hline WHO to formalise universal periodic peer reviews of national pandemic preparedness and response & WHO/national governments & Q4 2021 \\
\hline $\begin{array}{l}\text { IMF should routinely include a pandemic preparedness assessment in evaluation of national economic policy } \\
\text { response plans }\end{array}$ & International Monetary Fund & Q 3-4 2021 \\
\hline \multicolumn{3}{|l|}{ Establish a new agile system for surveillance, validation, and alerts } \\
\hline WHO to establish a new global system for surveillance. & WHO Secretariat & Q4 2021 \\
\hline WHO to be given the explicit authority by the World Health Assembly to publish information about outbreaks & WHA decision & May 2022 \\
\hline WHO empowered to investigate pathogens with pandemic potential in all countries & WHA decision & May 2022 \\
\hline $\begin{array}{l}\text { Future declarations of a PHEIC should be based on the precautionary principle where warranted. The Emergency } \\
\text { Committee must be fully transparent in its membership and working methods }\end{array}$ & WHA decision & May 2022 \\
\hline \multicolumn{3}{|l|}{ Establish a pre-negotiated platform for tools and supplies } \\
\hline $\begin{array}{l}\text { Transform the current ACT-A into a truly global end-to-end platform for vaccines, diagnostics, therapeutics, and } \\
\text { essential supplies }\end{array}$ & $\begin{array}{l}\text { National governments/member } \\
\text { states }\end{array}$ & Medium term \\
\hline Ensure technology transfer and commitment to voluntary licensing & National governments & Medium term \\
\hline Establish strong financing and regional capacities for manufacturing, regulation, and procurement & $\begin{array}{l}\text { National governments/WHO/ } \\
\text { regional institutions/private sector }\end{array}$ & Medium term \\
\hline \multicolumn{3}{|l|}{ Raise new international financing for the global public goods of pandemic preparedness and response } \\
\hline Create an International Pandemic Financing Facility & G20 and member states & $\begin{array}{l}\text { Before the end of } \\
2021\end{array}$ \\
\hline
\end{tabular}

pandemic threat. It would draw contributions from countries based on ability to pay, with larger and wealthier economies paying relatively more. The facility should secure funding streams that are not dependent on discretionary overseas development aid. Both the panel and the G20's High Level Independent Panel recommend that the facility mobilises10-15 year contributions of around \$5bn-\$10bn (£3.5bn- €7.4bn) a year to fill gaps in preparedness, ${ }^{13}$ and the panel proposed it have the ability to disburse up to $\$ 100$ bn for early response at short notice in the event of new pandemic threat. The panel did not recommend creating a new global fund, but that funds would flow through existing international and regional mechanisms.

\section{Strengthening the authority and independence of WHO}

To ensure greater speed and transparency in the face of pandemic threats, the panel recommends a more focused, securely funded, and independent WHO, with enhanced authority and the ability to investigate outbreaks and report rap- idly. Recommended measures to empower WHO include secure unearmarked funding with member state fees meeting two thirds of the base programme budget, and having a single seven year term of office for the director general and for each regional director. The panel concluded that WHO's mandate should focus on normative, policy, and technical guidance, including supporting countries and regions to build capacity for pandemic preparedness and response and for resilient and equitable health systems. WHO's working group on sustainable financing is discussing the panel's recommendations. ${ }^{14}$ Many of the panel's additional recommendations pertaining to WHO have been implemented, such as the synthesis of global vaccination targets and a subsequent strategy for achieving them, the establishment of a WHO hub for pandemic and epidemic intelligence, and WHO appointing a scientific advisory group for the origins of novel pathogens.

The panel has recommended that countries rapidly agree on a new pandemic framework convention, using the powers of article 19 of the WHO Constitution.
This convention or treaty would close gaps in the current legal framework, endorse principles for effective pandemic preparedness and response, establish norms and obligations of countries, and clarify the responsibilities between states and international organisations. ${ }^{15}$ The convention would complement the IHR and help ensure that these legally binding international instruments facilitate a proactive and rapid response to outbreaks with pandemic potential. The potential process for establishing a potential framework convention is the topic of the Special Session of the World Health Assembly in November 2021.

\section{Global public goods}

The Access to COVID-19 Tools Accelerator (ACT-A) platform was built organically, with the right intentions, but has too often failed to deliver tools and supplies to the areas of the world in most need. To ensure more equitable distribution, the panel recommends establishing a prenegotiated platform that shifts from the current charity and market driven approach to one aimed 
at genuinely delivering global public goods: non-rival and non-excludable goods that provide universal benefits. ACT-A should be transformed into a truly global end-to-end platform to deliver vaccines, therapeutics, diagnostics, and essential supplies rapidly and equitably. The panel emphasises that urgent measures are required to increase access to essential diagnostics and therapies for covid-19, including oxygen, and to meet the demands for equitable distribution of vaccines.

\section{Strategic and coordinated action}

The panel has not recommended that new global health institutions be created to respond to the failures that led to covid-19 becoming a catastrophic global pandemic. The organic evolution of the international health system over recent decades in response to particular health problems has resulted in pockets of substantial progress but also created inefficiencies resulting from unclear roles and responsibilities and an inability to leverage effectively the comparative advantages of different actors. ${ }^{16}$ The panel has therefore recommended concrete action designed to ensure that the international system, including civil society and private sector organisations, are more co-ordinated with better links between subnational, national, regional, and global levels in pandemic preparedness and response.

\section{Next steps}

The experience of the covid-19 pandemic must not be repeated, but the window of opportunity for securing the necessary change is short. The experience of previous epidemics shows that the appetite for change fades quickly once the emergency has passed. Commitment to the required reforms needs to be secured in the course of the coming months. The World Health Assembly Special Session in late November 2021 should serve as an opportunity not only to commence negotiations on a framework convention but, in the panel's view, as an opportunity to make crucial decisions regarding WHO's independence, financing, and authority. A political declaration by the UN General Assembly is a potential instrument to set out in a timely fashion international agreement at the highest level on strengthened pandemic preparedness and response, across multiple arenas and processes. Agreement of such a declaration could serve as an immediate focus for defining the steps forward and beginning the necessary processes and negotiations between member states.
Contributors and sources: This analysis was part of the work undertaken by the Independent Panel for Pandemic Preparedness and Response. Data for this review were collected under the auspices of the Independent Panel for Pandemic Preparedness and Response. The analysis of this paper is separate from the Independent Panel's Final Report and has been facilitated by the Independent Panel secretariat. The secretariat is independent and impartial. The views expressed here this work are solely those of the authors and do not represent the views of the Independent Panel. SS, MB, and HLQ conceived and designed the manuscript. SS and MB drafted the manuscript with inputs from all authors. All authors contributed to revising the manuscript and approved the final version. SS and MB are joint first authors.

Competing interests: We have read and understood BMJ policy on declaration of interests and have the following interests to declare: HLQ has worked as a consultant with WHO on unrelated projects and is a member of the WHO Europe high level expert consultation group on covid-19 strategies. MB has worked as a consultant with WHO on projects concerning gaps in pandemic preparedness, a global hub for pandemic and epidemic intelligence, and investment in WHO. SMA has worked as a consultant with WHO on unrelated projects and is the lead project director of a grant from the Rockefeller Foundation to examine the intersection of data, determinants of health, and decision making. AN has worked as a staff member at WHO including as acting director general and as a country representative.

Provenance and peer review: Commissioned; externally peer reviewed.

This collection of articles was proposed by The Independent Panel for Pandemic Preparedness and Response. Open access fees were funded by WHO and Singapore's National Medical Research Council (NMRC) CG/C026/2017_NUHS). The BMJ commissioned, peer reviewed, edited, and made the decision to publish these articles. Kamran Abbasi was the lead editor for The BMJ. Sudhvir Singh, adviser ${ }^{1,2}$

Michael Bartos, honorary associate professor ${ }^{1,3}$

Salma Abdalla, research fellow ${ }^{1,4}$

Helena Legido-Quigley, associate professor ${ }^{1,5,6}$

Anders Nordström, ambassador

Ellen Johnson Sirleaf, former president of Liberia Helen Clark, former prime minister of New Zealand ${ }^{7}$ ${ }^{1}$ Independent Panel for Pandemic Preparedness and Response Secretariat

${ }^{2}$ Faculty of Medical and Health Sciences, University of Auckland, New Zealand

${ }^{3}$ School of Sociology, Australian National University, Australia

${ }^{4}$ School of Public Health, Boston University, United States

${ }^{5}$ Saw Swee Hock School of Public Health, National University of Singapore, Singapore

${ }^{6}$ Department of Global Health and Development, London School of Hygiene and Tropical Medicine, UK ${ }^{7}$ Independent Panel for Pandemic Preparedness and Response

Correspondence to: M Bartos

michael.bartos@anu.edu.au

\section{(c) (1) (8)}

This is an Open Access article distributed under the terms of the Creative Commons Attribution IGO License (https://creativecommons.org/licenses/ by-nc/3.0/igo/), which permits use, distribution, and reproduction for non-commercial purposes in any medium, provided the original work is properly cited.
Check for updates

1 World Health Organization. Resolution WHA 73.1 COVID-19 response. https://apps.who.int/gb/ebwha/ pdf_files/WHA73/A73_R1-en.pdf

2 Independent Panel for Pandemic Preparedness and Response. COVID-19: make it the last pandemic. 2021. https://theindependentpanel.org/mainreport/

3 Baum F, Freeman T, Musolino C, et al. Explaining covid-19 performance: what factors might predict national responses? BMJ 2021;372:n91. doi:10.1136/bmj.n91

4 WHO. Report of the Review Committee on the Functioning of the International Health Regulations (2005) during the COVID-19 response. WHA A74/9 Add.1. Provisional agenda item 17.3. World Health Organization, 2021

5 World Health Organisation (WHO). Statement on the second meeting of the International Health Regulations (2005) Emergency Committee regarding the outbreak of novel coronavirus (2019-nCoV) [Internet]. [cited 2021 Apr 6]. Available from: https:// www.who.int/news/item/30-01-2020-statementon-the-second-meeting-of-the-international-healthregulations-(2005)-emergency-committee-regardingthe-outbreak-of-novel-coronavirus-(2019-ncov)

6 Sirleaf EJ, Clark H. Report of the independent panel for pandemic preparedness and response: making covid-19 the last pandemic. Lancet 2021;398:1013. doi:10.1016/S0140-6736(21)01095-3

7 Global Preparedness Monitoring Board. A world at risk. Annual report on global preparedness for health emergencies, 2019. World Health Organization, 2019.

8 Highlevel Panel on the Global Response to Health Crises. Protecting humanity from future health crises: Report of the High-level Panel on the Global Response to Health Crises [Internet]. New York: United Nations General Assembly; 2016. Available from: https://www.un.org/ga/search/view_doc. asp?symbol=A/70/723

9 Radin E, Eleftheriades C. Financing Pandemic Preparedness and Response Background Paper 14. [Internet] Independent Panel for Pandemic Preparedness and Response, 2021, Available from https://theindependentpanel.org/wp-content/ uploads/2021/05/Background-Paper-14-FinancingPandemic-Preparedness-and-Response.pdf.

10 Haldane V, De Foo C, Abdalla SM, et al. Health systems resilience in managing the COVID-19 pandemic: lessons from 28 countries. Nat Med 2021;27:96480. doi:10.1038/s41591-021-01381-y

11 The state of governance and coordination for health emergency preparedness and response. Background report commissioned by the Global Preparedness Monitoring Board. 2020. https://www.gpmb.org/ docs/librariesprovider17/default-document-library/ annual-reports/gpmb-2019-arbackgroundpaper1.pd $\mathrm{f}$ ?sfvrsn=122469ee 3 \&download=true

12 G7. Carbis Bay G7 Communiqué. Our shared agenda for global action to build back better. 2021.: https://www. g7uk.org/wp-content/uploads/2021/06/Carbis-BayG7-Summit-Communique-PDF-430KB-25-pages-1-1.pdf

13 G20 High Level Independent Panel. A global deal for our pandemic age. 2021. https://www.g20.org/ wp-content/uploads/2021/07/G20-HLIP-Report.pdf

14 World Health Organization. Third Meeting of the Working Group on Sustainable Financing 2021. https://apps. who.int/gb/wgsf/pdf_files/wgsf3/WGSF_3_2-en.pdf

15 Duff JH, Liu A, Saavedra J, et al. A global public health convention for the 21st century. Lancet Public Health 2021;6:e428-33. doi:10.1016/S24682667(21)00070-0

16 Spicer N, Agyepong I, Ottersen T, Jahn A, Ooms G. 'It's far too complicated': why fragmentation persists in global health. Global Health 2020;16:60. doi:10.1186/s12992-020-00592-1 